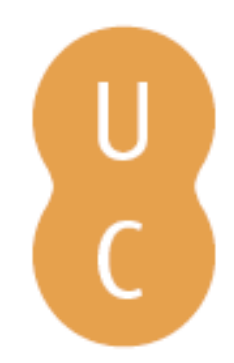

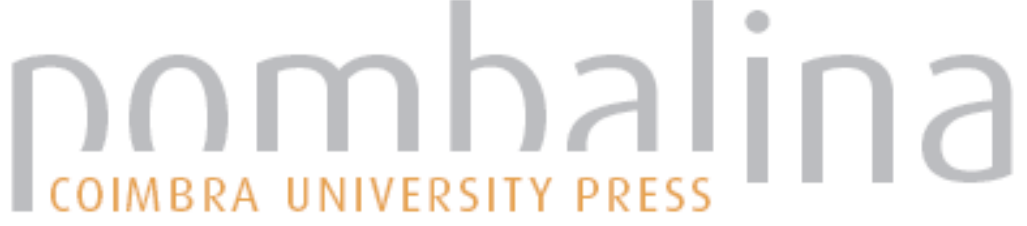

\section{Câmara Cascudo em Defesa de Epicuro}
Autor(es): $\quad$ Silva, Markus Figueira da
Publicado por: Imprensa da Universidade de Coimbra
URL persistente:
URI:http://hdl.handle.net/10316.2/37039
DOI:
DOl:http://dx.doi.org/10.14195/978-989-26-1043-6_4
Accessed : $\quad$ 26-Apr-2023 11:04:55

A navegação consulta e descarregamento dos títulos inseridos nas Bibliotecas Digitais UC Digitalis, UC Pombalina e UC Impactum, pressupõem a aceitação plena e sem reservas dos Termos e Condições de Uso destas Bibliotecas Digitais, disponíveis em https://digitalis.uc.pt/pt-pt/termos.

Conforme exposto nos referidos Termos e Condições de Uso, o descarregamento de títulos de acesso restrito requer uma licença válida de autorização devendo o utilizador aceder ao(s) documento(s) a partir de um endereço de IP da instituição detentora da supramencionada licença.

Ao utilizador é apenas permitido o descarregamento para uso pessoal, pelo que o emprego do(s) título(s) descarregado(s) para outro fim, designadamente comercial, carece de autorização do respetivo autor ou editor da obra.

Na medida em que todas as obras da UC Digitalis se encontram protegidas pelo Código do Direito de Autor e Direitos Conexos e demais legislação aplicável, toda a cópia, parcial ou total, deste documento, nos casos em que é legalmente admitida, deverá conter ou fazer-se acompanhar por este aviso.

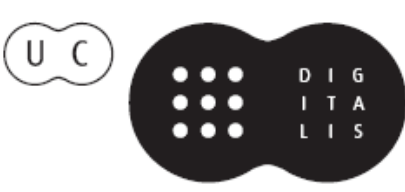


politica no Brasil do sécu

Categorias aristotélicas por Silvestre Pinheiro Ferreira - Musas errantes: tesouros da Antiguidade Clássica no labirinto da Biblioteca Nacional Brasileira - Eudoro de Sousa e a Mitologia • Câmara Cascudo em defesa de Epicuro - Medéia carioca - Ecos de Platão em Vergílio Ferreira - Imaginário clássico na poesia de António Arnaut - Motivos clássicos na poesia novilatina em Portugal: Manuel da Costa - Uma Ifigénia portuguesa: "Noite escura" de João Canijo • Uma leitura de Mau Tempo no Canal de Vitorino Nemésio $\bullet A$ phýsis grega e o Brasil: as viagens de Von Martius $\bullet$ Fantasia para dois coronéis e uma piscina. Ecos clássicos num contexto do séc. XX

\section{A RECEPÇÃO DOS CLÁSSICOS EM PORTUGAL E NO BRASIL}

Maria de Fátima Silva Maria das Graças de Moraes Augusto COORDENAÇÃo 


\section{SÉRIE MITO E (RE)ESCRITA}

ISSN: $2182-8814$

\section{PERIODICIDADE: Anual}

Apresentação: Poetas, pintores, escultores, na Antiguidade, familiarizados com mitos antigos de deuses e de homens, que cristalizavam experiências, interrogaçóes, respostas quanto à existência do homem no tempo e no mundo, em mitos se inspiraram, em contínua criação-recriaçẩo, para neles verterem a sua própria experiência temporal, com todos os desassossegos e inquietaçóes, com todo o espanto, horror ou encantamento pela excecionalidade da ação humana, que rasga ou ilumina fronteiras de finitude. Esses percursos da criação merecem, hoje, a atenção e análise dos Estudos Literários e, como não podia deixar de ser, dos Estudos Clássicos, muito peculiarmente. Importa, pois, proceder à publicação sistemática de estudos deste cariz, que se destaquem pela qualidade científica e pela originalidade, sendo dedicados, sobretudo, a autores de língua portuguesa. Assim se dá corpo à linha editorial MITO E (RE)ESCRITA.

Este livro, realizado no âmbito do Convénio de Cooperação Académica entre o CECH - Centro de Estudos Clássicos e Humanísticos da UC - e o PRAGMA - Programa de Estudos de Filosofia Antiga da UFRJ -, reúne um conjunto de estudos sobre a recepçáo de temas e modelos greco-latinos na literatura e cultura de Portugal e Brasil.

A sua originalidade resulta da participação de diferentes culturas e das especialidades académicas diversas dos investigadores que nele participam, provenientes da Literatura, da Filosofia e da História Antiga. O lapso de tempo abrangido, que vai do séc. XVI ao XX, permite uma visáo de conjunto da evoluçáo operada no perfil cultural de ambos os países e na definição de um trajeto em boa parte comum. 


\section{Câmara Cascudo em Defesa de Epicuro}

(Câmara Cascudo defending Epicurus)

Markus Figueira da Silva

Departamento de Filosofia da Universidade Federal do Rio Grande do Norte

(markus@cchla.ufrn.br) 
Página deixada propositadamente em branco 
Resumo - Em seu livro Prelúdio e Fuga do Real, Luiz da Câmara Cascudo dedica um capítulo a Epicuro, no qual apresenta uma análise do pensamento ético do filósofo helenista, destacando a incompreensão deste pensamento pelo senso comum. O cerne da análise cascudiana é o sensualismo de Epicuro que aparece matizado pela frugalidade que se opóe à imagem de dissoluto que erroneamente foi divulgada ao longo da história. O que se busca aqui é argumentar em torno da apresentação que Câmara Cascudo faz da ética de Epicuro, evidenciando a coerência deste pensamento e a sagacidade do seu intérprete brasileiro.

Palavras chave - literatura brasileira, recepção, epicurismo.

Abstract - In his Prelúdio e Fuga do Real, Luiz Câmara Cascudo, in a chapter dedicated to Epicurus, offers an analysis on the ethical thought of the Hellenistic philosopher, underlining the general incomprehension about it. The main point in Cascudo is Epicurus' sensuality combined with a frugality that contradicts his traditional image of dissolution. This article aims to explore the interpretation Cascudo makes of Epicurus, and to make clear the sagacity of the Brazilian interpreter.

KeYwords - Brazilian literature, reception, Epicureanism.

Câmara Cascudo ambienta o seu conto "Epicuro. Do prazer sem os sentidos" num cenário fictício e anacrônico, mas com elementos e nomes reais. Assim a cena tem lugar no Hotel Belvedere, em Nova York, lugar frequentado por pessoas que figuram no hall da fama e que cultivam a imagem - ou aparência - mas que são descritas como "técnicos da intranquilidade universal" ". Vê-se desde o início do texto a descriçẫo dos modos de vida excêntricos e imoderados, típicos daqueles que buscam cultivar a fugacidade e construir artificialmente uma glória forjada em aparentes honrarias, tal como fazem certos políticos que se acham deuses, artistas que um dia sentiram esperança de se tornarem famosas.

Toda descrição detalhada desse cenário preconiza o principal foco da abordagem cascudiana da crítica que Epicuro faria das apropriações indevidas do seu pensamento, que resultaram na ampla e criminosa divulgaçáo distorcida da sua imagem na História da Filosofia. Na verdade a descrição das personas que frequentam o hotel póe em evidência as crenças ilusórias e as vấs opinióes que povoam o vazio que sustenta, imaginariamente, a conduta dessas pessoas. Antevê-se os modos de vida marcados pela ausência de discernimento (phrônesis), aqueles que sempre foram objeto da crítica epicurista, os incapazes de perceber a alternativa apontada por Epicuro

\footnotetext{
1 Câmara Cascudo 1974: 25.
} 
para este modo de vida ilusório e intranquilo, que aprisiona os ignorantes nas amarras de uma condição de vida artificial e sem porvir. Somente no sétimo parágrafo, Cascudo inicia a descrição da personagem central do conto, Epicuro de Samos, filósofo grego que viveu entre 341 e 270 a. C.:

Cabelos de prata, olhos negros, perscrutadores, lento, majestoso, alheado, vestido de escuro, folgado e cômodo, como um Doctorof Divinity. Folheia, indiferente e maquinal, as publicaçôes do living room. Fuma um cachimbo de barro branco, com saboreado vagar, olhando longe, através do parque, molhado de chuva, ou dourado de sol... um "jequitibá em planícies de jurubebas²."

Percebe-se já nessa descrição a imagem de Epicuro construída a partir dos dados recolhidos na leitura do livro X das Vidas e Doutrinas dos filósofos Ilustres, de Diógenes Laércio, que certamente foi a sua principal fonte, seguida do poema De Rerum Natura, de Lucrécio, nas versōes francesa e italiana. Contudo o que nos interessa na sua leitura e na sua interpretação é o humor com que escreve a sua séria defesa do pensamento de Epicuro contra "mais de vinte séculos de deformação intencional e visão de escândalo", como ele mesmo asseverou ${ }^{3}$. Devemos chamar a atençáo para o personagem, um professor aposentado de uma universidade americana, aqui identificado a Epicuro, que se encontra no saguão do hotel fazendo um comentário sobre um volume de História da Filosofia que tem nas mãos: "veja que os gregos estão quase legítimos" e "Epicuro, quase verdadeiro", acrescentando que Epicuro "é o mais inverídico dos filósofos". O professor, isto é, Epicuro, mesmo que fictício, acrescenta que "o falso Epicuro é proveitoso aos seus adversários”. Perguntamos então: quais adversários? E a resposta vem a seguir: "peripatetas, estóicos, sofistas e platonianos, enriquecidos depois pela convergência sonora da loquela cristã".

Outra informação colhida de Diógenes Laércio é a produção de mais de trezentos livros que desapareceram e Cascudo explica as razóes desse desaparecimento:

"Ele (Epicuro) não tivera as transcrições simpáticas que Sócrates mereceu de Platão", e ainda: "Ficou sendo a égide das tendências inferiores

\footnotetext{
2 Cascudo 1974: 25

3 Cascudo 1974: 26.

4 Cascudo 1974: 26.
} 
e sujas, impotente suíno fuçador de detritos e lameiros humanos, devoto do ventre e de falos... filósofo das orgias e bacanais." 5

É como se Epicuro soubesse da infame caricatura que a maledicência registrou ao longo de toda história até o momento que ele, Epicuro, resolveu falar como personagem de Cascudo. Prova disso é o que Cascudo encontrou nos dicionários quando buscou o verbete Epicurismo: "Teoria de requintes, fruição utilitária, volúpia incessante dos sentidos”. Então ele deu voz a Epicuro para se defender:

"Prazer! Razão de viver! Da vida, nada levamos. Prêmios, castigos, julgamento, suplícios, sấo inexistências criadas pela má digestão do agape. Alma é uma função orgânica, como o fígado. Dissipa-se na morte. Entregue seu tempo aos instintos aprazíveis. Deixe o mando, governo, poder, para as vocações prisioneiras da angústia!" ${ }^{6}$

Cascudo é irônico quando se refere às barbaridades que disseram de Epicuro e do Epicurismo. Ele pondera que nada compreenderam, porque não tomaram conhecimento do pensamento genuíno de Epicuro. O que divulgaram foi apenas a imagem que divulgaram do filósofo, por isso decreta que a partir deste momento o personagem Epicuro se declarará e falará de si e do seu pensamento na primeira pessoa, para mostrar o alcance que teve e o porquê de ter servido em momentos distintos de emblema difamador daqueles que, posteriormente, assumiram e divulgaram as suas ideias:

"Sou Epicuro de Samos, filho de Aristóbolo e Cherestrata, sábio de Atenas. Fui o primeiro grego afirmando-se com esse título. Os senhores não antepõem o douto, o doutor, ao nome próprio?” 7

Quando o personagem Epicuro se revela ao leitor, revela também que se transportou no tempo para uma cena contemporânea, vivida por Cascudo, leitor voraz de tudo que chegou até ele. A ficção possibilita um olhar retrospectivo que exibe o contraste entre os estudos sérios da filosofia antiga e a falsa imagem divulgada para fomentar a ignorância e servir os interesses da "convenção e da malícia", como afirmou em sua autodefesa.

\footnotetext{
5 Cascudo 1974: 26.

6 Cascudo 1974: 26-27.

7 Cascudo 1974: 27.
} 
Cascudo cita Ubertino de Cezara e Erasmo de Rotterdam como vítimas políticas e ideológicas, o primeiro considerado herege e o segundo chamado pejorativamente por redimir Epicuro de toda essa difamação; só em 1889, Hermann Usener publica a sua Epicurea, "maciça comprovação e colheita do resto que de mim existe, mesmo parcialmente desfigurado, não poderia evitar a continuidade da avalanche estrondeando perfídias". (27). O que se nota é que Cascudo não tem o objetivo de forjar semelhanças entre Epicuro e os estóicos, nem tampouco "cristianizar" o pensamento epicurista como fez Francisco de Quevedo em $1635^{\circ}$. Náo creio que Cascudo tenha tido acesso a essa obra, mas de todo modo a sua intenção, além de satirizar a maledicência como bobagem servil da ignorância, foi mostrar como Epicuro gostaria de ser apreciado pelos leitores e qual a sua real importância. Assim ele tematiza, resumidamente, os principais pontos da filosofia epicurista, segundo a leitura de comentadores que se apoiaram nas fontes textuais genuínas, a saber: o livro $\mathrm{X}$ da obra de Diógenes Laércio e o poema De Rerum Natura, de Lucrécio, além da doxografia e das citaçóes recolhidas por Usener.

Mesmo com o esforço dos estudiosos do pensamento de Epicuro e da reuniáo dos textos remanescentes da sua obra, o que resta é muito pouco e Cascudo sugere qual a opinião de Epicuro sobre os seus escritos na atualidade:

\footnotetext{
"Não creio ser possível reconstruir todo o navio pelo aproveitamento dos destroços salvos. Quanto à sua essência incorruptível há, ou resiste, mais do que suficiente para a evidência, justamente o inverso da imagem divulgada" ?.
}

O que Cascudo denominou "essência incorruptível" diz respeito à physiología e à ética epicurista. Diversos comentadores concordam que é notória a influência do atomismo antigo no desenvolvimento da ciência moderna em diversos aspectos, assim como é reconhecida por diversos pensadores a importância da ética de Epicuro, preservada nas assertivas da Carta a Meneceu, das Máximas Principais e das Sentenças Vaticanas. A questão fundamental da ética é o modo de vida sábia, onde a physiología é a pesquisa acerca da natureza das coisas e define-se como exercício contínuo que caracteriza a prática filosófica no Jardim. Neste sentido, o modo de vida sábia

\footnotetext{
8 Quevedo 1986.

9 Cascudo 1974: 28.
} 
preconiza o kathá physin, que significa viver de acordo com a natureza. Os estudos sobre o epicurismo, em particular sobre a prática de vida de Epicuro, evidenciam a simplicidade, a frugalidade da vida na comunidade epicurista. É o que assevera o Epicuro de Cascudo:

"Já disse que tivera contra mim os herdeiros de Aristóteles e de Platão, sofistas loquazes e estóicos teatrais. Vivi setenta e um anos de equilíbrio, prudência, comedimento. Por convicção, que a vacilante saúde colaborara, fui homem frugal...” ${ }^{10}$.

Ele fala de si e da vida que levou, da sua magnanimidade em libertar os escravos e doar o Jardim aos amigos para a continuidade do modo de vida que concebera e cultivara. Diz que a sua escola fora dos muros de Atenas "possuiu duração tranquila" "11, mesmo tendo vivido em uma época de perseguiçóes e tormentos, como ele relata a seguir:

"Não seria crível essa tolerância para um escolarca do vício e da subalternidade moral. Sócrates e Pródico beberam cicuta. Protágoras morreu, fugitivo, no mar. Aristóteles conheceu o exílio. Vivíamos no caos que a morte de Alexandre Magno determinara. Seus generais fundavam reinos com espada e sangue. Os descendentes de Alexandre foram trucidados pelo crime dessa perturbadora ascendência. Ninguém interrompeu minhas aulas à margem d'água corrente, sob sombras mansas e longas" ${ }^{12}$.

Ainda sobre o modo de vida epicurista, diz a descrição cascudiana na voz do personagem Epicuro:

"Os epicuristas não seriam heróis nem mártires, mas sábios, gente humana, valorizando a calma, alegrias da convivência letrada, a suprema volúpia do entendimento, que era a compreensão e renúncia às formas troantes da tempestade administrativa, econômica, guerreira" ${ }^{13}$.

\footnotetext{
10 Cascudo 1974: 27.

11 Cascudo 1974: 28.

12 Cascudo 1974: 28.

13 Cascudo 1974: 28.
} 
a) Aspectos do pensamento de Epicuro evidenciados por Câmara Cascudo.

Em primeiro lugar, a physiología e a gnoseología, o exercício da compreensão da phýsis com vistas à realização da vida sábia. Cascudo inventa um Epicuro que justifica a diferença que marca a sua postura investigativa frente a outros pensadores. Mostra a coerência e a lucidez de Epicuro quando aponta o sentido prático e conveniente da physiología e da gnoseología por ele concebidas.

\begin{abstract}
"Os aristotélicos, platônicos, estóicos, sofistas e cristãos ensinavam e ensinam que a ciência, física ou moral, deve ser servida pelo homem, submetido permanentemente aos seus impositivos como a um deus exigente, imperioso, implacável. Eu (Epicuro) inverti os termos da proposição. A ciência (physiología e ética) deve estar em serviço do homem, ampliando as dimensões inteligíveis da existência, ou não será ciência alguma. Fora do humano, do perceptível e útil, cognoscível pelos sentidos, verificável pela repetição experimental, nada interessará nossa cogitação. O sol terá milhóes de formas ativas no universo, mas para nós ilumina, aquece, fecunda a terra... Fixemo-nos na terra, tratando de viver sem os problemas do sofrimento. Bastam os do próprio organismo pessoal"14.
\end{abstract}

Cascudo mostra o que o interessou na leitura dos textos filosóficos de Epicuro e da sua biografia composta por Diógenes Laércio. Ele se posiciona a favor de Epicuro por este não desvincular o conhecimento da sua realização prática, nem da sua conveniência, ou utilidade (sympheron). Ele também mostra sua aprovação do modo de vida indicado por Epicuro, traçando um perfil claro da ética epicurista, a começar pela afirmaçáo da autarkeía, isto é, da defesa desta noção fundamental para a conquista e para o exercício da liberdade (eleuthería) do sábio. Cabe ao sábio ser autárquico, ou seja, ter o princípio da ação nele mesmo. Só assim poderá escolher e recusar, o que em essência é a sua liberdade. Libertar-se dos temores provocados pela ignorância e alimentados pelas opinióes vazias.

"Viva e deixe os outros viverem! o espírito é ansioso e móbil, mas além da física, do corpo, dos átomos, existe unicamente a dor do mistério. Notadamente no plano do sobrenatural influindo na movimentação humana"15.

14 Cascudo 1974: 28.

15 Cascudo 1974: 30. 
A physiología constitui um exercício de busca pelo saber que possa dar ao homem a sua ataraxia (imperturbabilidade da alma). Escolher pensar a phýsis e evitar acreditar nos mitos. É o exercício da Physiología que livrará o sábio dos temores que o atormentam e assim ele tornará a sua vida esclarecida e aprazível. A sabedoria atuará como um phármakon, isto é, como um tetraphármakon, prescrevendo o modo de agir com sensatez e discernimento frente aos temores da alma. Epicuro afirmou que "não há nada a temer em relação aos deuses", como o primeiro dos quatro remédios e Cascudo defende Epicuro da acusação de impiedade, resultado dessa afirmação:

“-Não! Não neguei os deuses. Ignorei-os apenas como dispensáveis grandezas na humildade da terra. $\mathrm{O}$ senhor não acha ridícula essa frase? Combater, negar os deuses? A devoção e a incredulidade são valores puramente humanos. Não alcançam a divindade infinita que deles independe. Que alteração substancial terão os deuses com a nossa estima ou negativa? Viverão pela nossa fé?" 16

Cascudo enfatiza que para o personagem Epicuro, na sua visão retrospectiva, "a face reprovada do epicurismo, a mais frágil da doutrina", é a moral. ${ }^{17} \mathrm{E}$ continua a defesa em forma de justificativa:

"Não incluí os deuses porque ainda permanecem difusos, confusos, complexos, para os humanos... o conhecimento dos deuses é um mistério sem iniciaçấo"18.

Curiosamente Cascudo não reconstrói os preceitos acerca da morte e da dor, que compóem, junto com os deuses e o prazer, o tetraphármakon. Contudo, ele realça a recusa da política e propóe uma definiçâo epicurista da moral. No primeiro caso, Epicuro se defende da acusação de "indiferença precavida" ${ }^{19}$ em relação ao poder político e aos negócios públicos, nestes termos:

"Vivendo em época demagógica, recomendei abstenção partidária aos meus discípulos... Pítaco, aisenmeta de Mitilene, depois do decênio

\footnotetext{
16 Cascudo 1974: 31.

17 Cascudo 1974: 32.

18 Cascudo 1974: 31.

19 Cascudo 1974: 31.
} 
recusou reeleição, alegando: - é difícil proceder bem até o fim!" ${ }^{20} \mathrm{E}$ continua: "A tranquilidade intelectual vale uma dúzia de coroas de reis. Quem acredita nessa compensação? Unicamente os verdadeiros discípulos de Epicuro. Os demais atrelam ao carro dos negócios-públicos. Tornam-se públicos negócios...” ${ }^{21}$

Cascudo demonstra nutrir uma especial simpatia pelo modo de vida cultivado por Epicuro, sobretudo pela recusa do sábio em participar da vida pública e preferir "viver ignorado (lathe biósas)" (Epicuro/Us. 327-8)22. Parece compreender que a Atenas de Epicuro já não era livre e que a liberdade possível dependia do cuidado de si, do exercício da autarkeía. Por isso insiste na defesa da sua ética:

"Dispus a moral como elemento autônomo do céu e da terra, independente de retribuição econômica, sobrenatural ou repressiva. Uma entidade autárquica, bastando-se a si mesma. Recusando troféus e não temendo o inferno. Agindo com a naturalidade da respiração... causando prazer no seu simples exercício pessoal... Homem sem moral era organismo sem o músculo cardíaco"23.

Ele chama a atenção para a importância que teve a ética epicurista, por ele chamada de moral, em seu tempo e exime-se da responsabilidade sobre as interpretaçóes forjadas pela crítica tendenciosa daqueles que adulteraram o propósito da conduta sábia de Epicuro;

"Não é novidade, professor! É doutrina exposta entre 304 e 270, antes de Cristo, em Atenas. Não me cabe culpa da mudança ou dilaceração do invólucro. A finalidade humana é o prazer! Não o passageiro, efêmero, imediato, e que provocará o sofrimento, miséria, enfermidade, como um excesso de festim, de erotismo ou de ambição. Não vivemos para a renúncia, penitência, martírio" ${ }^{24}$.

\footnotetext{
20 Cascudo 1974: 31.

21 Cascudo 1974: 31.

22 Silva 2003: 94.

23 Cascudo 1974: 34.

24 Cascudo 1974: 35.
} 
Assim começa o último ponto da defesa que o Epicuro de Câmara Cascudo faz do seu próprio pensamento. A defesa do bem primordial e congênito, da noção de hedoné.

"O prazer para nós é o prazer contínuo e tranquilo, a calma da sabedoria (phrónesis) acima dos furores da paixão animal, prazer da fruição moral, íntima, suficiente ao ser racional"25.

Ele enaltece a noção de hedoné katastematiké, ou o prazer em repouso, que deixa a alma serena, conforme a imagem da superfície do mar em calmaria, definido na noção de galenismós.

"O homem, mesmo imperfeito e carecente, projeta e constrói a sua felicidade (makários zén), o prazer relativo ao júbilo da sua vida intelectual, desambiciosa, sorridente, modesta, recatada, fora da batalha dominadora"26.

Entretanto, a outra imagem forjada pelos detratores do epicurismo contrasta totalmente com aquela "ataraxía ambicionada e benéfica, a paz imperturbável e soberana" ${ }^{27}$. Eles inverteram o propósito dos ensinamentos e da prática de vida epicurista reconhecida por Cascudo pela frugalidade ética em oposição ao desperdício político ${ }^{28}$.

Por fim, o personagem Epicuro de Samos se despede do seu interlocutor dizendo o que pretendeu com a sua prática filosófica centrada no ideal de vida sábia, afirmativa do prazer:

“- Pretendi revelar a cada ser humano sua força interior, espiritual, capaz de fazê-lo encontrar-se, bastar-se, jamais sentir-se isolado, sozinho, desamparado... Não sonhei reformar uma sociedade, mas fortalecer o elemento essencial da componente, dar-lhe vigor, compreensão, ternura para as coisas simples e vitais. Outros prometeram a perfeição na terra ou a felicidade no céu. Eu apenas ensinei a encontrar-se a tranquilidade..." ${ }^{29}$

\footnotetext{
25 Cascudo 1974: 35.

26 Cascudo 1974: 35.

27 Cascudo 1974: 35.

28 Silva 2003: 95.

29 Cascudo 1974: 36.
} 
Markus Figueira da Silva

\section{Bibliografia}

Cascudo, L.C. (1974), Prelúdio e Fuga do Real. Natal: Fund. José Augusto.

Laércio, D. (2008), Vidas e Doutrinas dos Filósofos Ilustres. Brasília: UNB.

Lucrécio, T. (1964), De la Nature. Paris: Les Belles Lettres.

Quevedo, F. (1986), Defensa de Epicuro contra la comúm opinión. Madrid: Tecnos.

Silva, M.F. (2003), Epicuro, sabedoria e jardim. Rio de Janeiro: Relume Dummará. 
Maria de Fátima Sousa e Silva é Professora Catedrática do Instituto de Estudos Clássicos da Universidade de Coimbra. Desenvolveu, como tese de doutoramento, um estudo sobre a Comédia Grega Antiga (Crítica do teatro na Comédia Grega Antiga), e, desde então, tem prosseguido com investigação nessa área. Publicou já traduções comentadas de nove comédias de Aristófanes, além de um volume com a tradução das peças e dos fragmentos mais significativos de Menandro.

Maria das Graças de Moraes Augusto é Professora Titular no Departamento de Filosofia do Instituto de Filosofia e de Ciências Sociais da Universidade Federal do Rio de Janeiro (UFRJ). A sua investigação sobre História da Filosofia Antiga abrange temas como Platão e a herança platónica, filosofia e conhecimento no pensamento antigo, filosofia e literatura na tradição antiga e recepção dos clássicos gregos no Brasil.

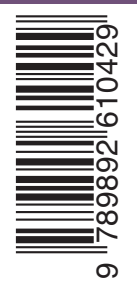


OBRA PUBLICADA

COM A COORDENAÇĀO

CIENTÍFICA
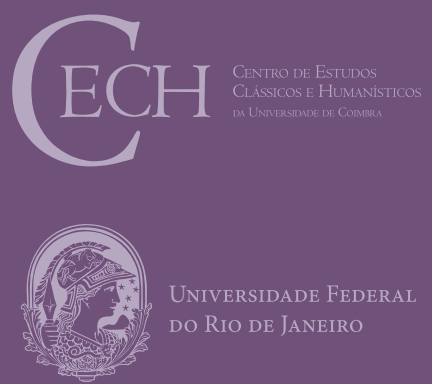

- U 